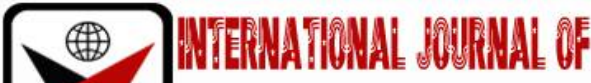

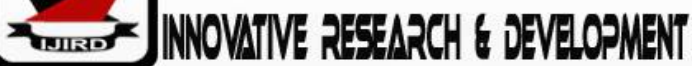

ISSN 2278 - 0211 (Online)

\section{Influence of Involvement in Co-Curricular Activities on Students' Commitment to Democratic Values}

Gachara John
Student, Masaai Mara University, Thika, Kenya
Dr. Sammy M. Mutisya
Senior Lecturer, Maasai Mara University
Narok, Kenya
Dr. Ruth Choge
Senior Lecturer, Bomet University College, Bomet, Kenya

\begin{abstract}
Ever since the declaration of modern democracies such as USA in 17th Century, the pursuit for commitment to democratic values has remained at the core of nations which are inclined towards democratic ideology. A companying this pursuit, has been the debate of appropriate means by which, young citizens in these nations can be made to adapt democracy as a life value. Although many democratic nations such as Kenya have opted to foster it through education, the potential of various frames of their school systems (such as co-curricular activities) in cultivating this democratic desire, have remained unempirical verified. In effort to fill this gap, this study aimed at verifying the potential of various co-curricular activities in influencing students' commitment to democratic values. In so doing the study sort to find whether there were significant differences in commitment to democratic values between students involved in social movements, talent enhancement and academic enhancement co-curricular activities. The study was conducted among public secondary schools in Kiambu County, Kenya. A total of 430 students were involved drawn from target population of 28,213 Form IV students using stratified proportionate random sampling procedure. The study results revealed that, there were statistical significant differences in commitments to democratic values among students involved in talent enhancement, academic enhancement and school social movement co-curricular activities at $(\mathrm{F}(2,340)=4.70, \mathrm{p} \leq 0.01)$ with Tukey's test indicating talent enhancement was significantly different from other two co-curricular activities. Multiple regression on co-curricular activities yielded a significant regression equation $(F(3,339)=5.563, p \varangle 0.001)$ with $R^{2}$ of .047 . Thus, confirming that, there were variations in influence of different co-curricular activities on students' commitment to democratic values.
\end{abstract}

Keywords: Talent enhancement, academic enhancement, school social movement, commitment to democratic values, cocurricular activities

\section{Introduction}

One of the most cherished governance ideology in the world today is known as democracy. Democracy as an ideology is founded on the belief that all members of a society (individuals, states, organisations, institutions and agencies) are equal partners in social, political and economic rights for leading and being led (Dagger, 2002). Although democratic ideology may vary in formation and implementation, one of the fundamental common content is democratic values. Subba (2014) describe democratic values as the fundamental beliefs and constitutional principles, which unites the society as they are mentioned and expressed in the declaration of independence of many countries. For example; The United States which subscribes to liberal federal democracy express its core democratic values in its declaration of independence and constitution as follows; right to life, liberty, common good, justice, truth, patriotism, popular and sovereignty (Burgan, 2006). In the spirit of democratic ideology, Kenya have prescribed on its constitution democratic values that can be categorised into four as shown in Table 1. 


\begin{tabular}{|c|c|l|}
\hline S/ N & Classification of Values & \multicolumn{1}{|c|}{ Democratic Values } \\
\hline 1. & Respect to individual rights & $\begin{array}{l}- \text { liberties, dignity, non-discrimination and } \\
\text { protection of the marginalized }\end{array}$ \\
\hline 2. & upholding national patriotism & $\begin{array}{l}\text { Equity \& equality } \\
\text { social justice \& inclusiveness }\end{array}$ \\
\hline 3. & Practicing common-good & $\begin{array}{l}\text { National unity, Sharing \& devolution of power, } \\
\text { Fidelity to Rule of law, Participation of people }\end{array}$ \\
\hline 4. & $\begin{array}{c}\text { Responsiveness to social } \\
\text { challenges }\end{array}$ & $\begin{array}{l}\text { Good governance, Transparency, Integrity, } \\
\text { appreciation }\end{array}$ \\
\hline
\end{tabular}

Table 1: Classification of Kenya democratic values

Source: The Constitution of Kenya, 2010

However, nations subscribing to democratic values through their constitutions across the globe over the years, have continued to experience; growing rate of violence, political exploitation, ever-increasing terrorism and state corruption (Subba, 2014). This has been contrary to the expectations of principles of democracy, which are believed to be facilitators of civil order and peace. In this same nations the civil disobedience has not only been experienced in general public but over the years it have been seen to manifest itself into institutions of learning such as secondary schools. For instant in Kenya, since the advent of expanded democratic space through re-introduction of multiparty democracy in 1992, the country has continued to experience ever increasing students' violent civil disobedience in public secondary schools.Case in point is where in the year 2016 alone, a total of 483 secondary schools registered incidences of students' violent-civil disobedience. This incidences occurred despite introduction of students' councils and inclusion of students in school boards of management (BOM) as means of institutionalization of its constitutional democratic values in institutions of learning (Daily Nation, 7 July 2018).

The occurrence of such scenarios have continued to precipitate the need for such nations as Kenya to go beyond inclusion of democratic values in constitution and public policies to striving to gaining commitment to democratic values among its citizens. This practice is in concurrence with views of Gafoor (2015), who observed, that democratic values should not only be desired by democratic nations but practical efforts should be made to ensure citizens develop their commitment. This means democratic nations must endeavour to cultivate commitment to democratic values among its current and future generations (such as secondary school students) as means for mitigating negative occurrences such as violent civil violence and safeguarding their democracy beyond tomorrow.

This cultivation of commitment to democratic values may be described as imparting sufficiently strong emotional and intellectual acceptance of democratic values (Cohen, 2003). It entails internalisation of a set of specific ideals, values and practices among others. In most democratic nations of the world Kenya included, this cultivation is mainly vested in education institutions such as secondary schools. This is due to their natural strategic placement on the cycle of human growth and development. Secondary school students who are also referred as teenagers, they are in transition stage to adulthood and they are psychologically pre-occupied with urge for self-discovery and in search for one's identity. This provide conducive ground for cultivation of commitment to democratic values.

According to Dahl (2015) Secondary Schools in democratic perspective are not only viewed as institutions that impart certain knowledge and skills to students, but also as environments that would socialize them into young democrats. On his observations, Mohmood (2012) describes schools as one of the cardinal means of controlling habits and characters in a complex social set-ups such as a nation. Tyler (1949) in his part argues that the purpose of schooling should be closely tied to addressing problems of contemporary society. He sees school as the agency for helping young people to deal effectively with the critical problems of contemporary life. In concurring with this observations, Olouch (1998) indicated that, the role of curriculum in schools, is to identify community challenges and organize them into goals, objectives, aims and learning outcomes to be achieved at the different levels of education and training. In so doing Olouch (1998), further notes that curriculum is known to occur in three dimension; informal curriculum, formal curriculum and non-formal curriculum.

The formal dimension may be described as that aspect of the school curriculum which consists of those learning activities that students undertake formally as in class as well as the curriculum objectives and student assessment methods that relate to them (Okumbe, 2004). On its part, informal dimension of curriculum entails what students learn through interaction with the environment where they are growing up, either in school or home. The non-formal dimension refer to school programmes offered outside academic framework on both regular or adhoc basis. In Kenyan secondary schools, non-formal curricular include; co-curricular activities, pastoral programmes, guidance and counselling programmes, student leadership programmes among others (Okumbe, 2004). These programmes are mainly designed to supplementing academic programmes through; promotion of talents, peer learning and enhancing positive social behaviour. There activities are usually offered through formal groups which create social-environments that mirror larger society establishments and practices (Ahmad, 2015).

According to a review by Smit (2011) among the non-formal curricular regular programmes in schools, cocurricular activities accounts for widest scope of students' engagement. He further observed that, co-curricular activities as social-environmental formations, presented platforms within schools that are characterized by; high level of flexibility, wide spectrum of human behavior experiences, highly receptive to individual innovations, expanded freedom of operation 
through self-regulation and voluntary admissions. Hence, positioning it as potential ground for cultivation of commitment to democratic values among students. In concurrence Weber (2008), describe co-curricular activities as widest educational programmes that are organised outside class hours and are designed either to supplement or complement the main syllabi activities. He further classify them into three broad categories namely; talent enhancing activities, academic complimentary activities and student social movements. A reflection on the three categories of co-curricular activities in reference to education practices in Kenya is illustrated in table 2

\begin{tabular}{|c|c|c|c|}
\hline $\mathbf{S} / \mathbf{N}$ & $\begin{array}{l}\text { Classification of Co- } \\
\text { Curricular Activities }\end{array}$ & Co-Curricular Activities & $\begin{array}{l}\text { Principle Purpose of The } \\
\text { Activities }\end{array}$ \\
\hline 1. & $\begin{array}{l}\text { Talent-Enhancement } \\
\text { Activities (TEA) }\end{array}$ & $\begin{array}{ll} & \text { Sports \& games } \\
\text { - } & \text { Performing arts (Drama \& } \\
\text { Music) } & \\
- & \text { Visual arts (fine Art) }\end{array}$ & $\begin{array}{l}\text { - To arouse and develop } \\
\text { various talents among the } \\
\text { students }\end{array}$ \\
\hline 2. & $\begin{array}{c}\text { Academic- } \\
\text { Enhancement Activities } \\
\text { (AEA) }\end{array}$ & $\begin{array}{l}\text { - Subject based clubs such as } \\
\text { science clubs, geography clubs, fine } \\
\text { art mathematics clubs, Debate clubs }\end{array}$ & $\begin{array}{l}\text { - To promote peer } \\
\text { support and informal set-ups in } \\
\text { learning and applying the } \\
\text { formal curriculum }\end{array}$ \\
\hline 3. & $\begin{array}{c}\text { School Social } \\
\text { Movements (SSM) }\end{array}$ & $\begin{array}{l}\text { - Religious movements such } \\
\text { as Christian unions, Catholic } \\
\text { associations, Muslim associations } \\
\text { - } \quad \text { Non- religious associations } \\
\text { and movements such as scouts, red- } \\
\text { cross, Award schemes, girl-guide }\end{array}$ & $\begin{array}{l}\text { To inculcate the values } \\
\text { and principles of the parent } \\
\text { associations as practiced in } \\
\text { larger society }\end{array}$ \\
\hline
\end{tabular}

Table 2: Classification of the Co-Curricular Activities

Source: An Adaptation of Weber (2008) To Kenyan Scenario

The table 2.0 illustrate the co-curricular activities as categorised according to their principle purpose in school operations. The talent enhancement co-curricular activities are illustrated as those activities oriented on identifying the inner hidden energies and abilities of the students. Academic complimentary co-curricular activities are illustrated as the activities designed in such a way to enhance application of academic knowledge and or promote peer learning. The school social movements' co-curricular activities are essentially illustrated as activities to propagate specific social values owned as prescribed by parent organization which are based on larger society. A review of literature related to these three categories of co-curricular activities groups have revealed that, there exist a strong correlation between the secondary school students' personality trait development and their participation in co-curricular activities (Mohmood, 2012). However, despite such likelihood of co-curricular activities to influence modification of student social behavior, there has been no specific empirical study linking co-curricular activities to inculcation of students' commitment to democratic values. Thus creating a need for a study that would empirically verify and affirm the existence or non-existence of significant influence of involvement in co-curricular activities on students' commitment to democratic values. This provided the basis for this study.

\subsection{Objectives of the Study}

The objective of the study was to verify difference in commitment to democratic values between students involved in talent enhancement, academic enhancement and students' social movements' co-curricular activities in Kiambu County, Kenya.

\subsection{Hypotheses of the Study}

- Ho There is no significance difference in commitment to democratic values among students involved in talent enhancement, academic enhancement and students' social movements' co-curricular activities.

\section{Methodology}

This study which used ex-post-facto research design was conducted among the public secondary schools students in Kiambu County. Kiambu County is located in central part of Kenya, in the year 2017 when this study was conducted, there were 289 public secondary schools with students up to Form IV. Drawing from these schools, the study target population was 28,213 Form IV students (i.e. secondary school final year students). Out of this population using proportionate stratified random sampling procedure, a sample of 430 Form IV students were selected. For the purpose of data collection, a structured self-administered student questionnaire was used. The questionnaire had three sections; section one focused on demographic information; section two was to determine the co-curricular activity that student was a member. The third section was Scale for measuring students' Commitment to Democratic Values adapted from Abdul Gafoor (2015) Scale for Commitment to Democratic Values (SCDV). The students'-SCDV had four (4) sub-scales with each having twelve (12) items making a total of 48 items of five (5) point Likert scales. The four sub-scales were to determine the students' Commitment on; respect to Human Rights, practicing common good, upholding national patriotism and responsiveness to social challenges respectively. 
Using this scale, the study tested if there were difference in commitment to democratic values among students involved in Talent Enhancement, Academic Enhancement and Students Social Movement co-curricular activities. One Way-ANOVA was used to test if the means for each category of co-curricular activity were statistically significantly different from each other, while Tukey Test tested which co-curricular activities were statistically different from each other. Multiple regressions were finally used to weigh the magnitude influence of the three co-curricular activities (Talent Enhancement, Academic Enhancement and School Social Movements) on students' commitment to democratic value. The level of significance for the three tests was set at $\alpha=0.05$. The results for the mean scores, ANOVA test, Tukey's test and Multiple Regression analysis were as shown in tables 3.1, 3.2, 3.3, 3.4 and 3.5 respectively.

\section{Results and Discussions}

Out of 430 students who participated on the study 343 (80.1\%) students were involved in co-curricular activities and $87(19.9 \%)$ students were not involved. The mean scores and variation of students' commitment to democratic values for students involved in different types of co-curricular activities were analyzed. In the analysis, the co-curricular activities were categorized according to Weber (2008) classification as earlier alluded. The results were presented as shown on Table 3.

\begin{tabular}{|c|c|c|c|}
\hline Involvement in Co-curricular Activities & M & SE & N \\
\hline Talent Enhancement & 79.92 & 8.34 & 157 \\
\hline Academic Enhancement & 77.34 & 7.78 & 111 \\
\hline School Social Movements & 80.84 & 9.34 & 75 \\
\hline TOTAL & 79.29 & 8.49 & 343 \\
\hline
\end{tabular}

Table 3: Mean Scores and Variations of Students' Commitment to Democratic Values in Accordance to Involvement in Co-Curricular Activities

Results in Table 3 revealed that the means for students' commitment to democratic values within the three cocurricular activities were different; $(M=79.92, S D=8.341)$ for Talent enhancement, scores $(M=77.34, S D=7.782)$ for Academic Enhancement and ( $\mathrm{M}=80.84, \mathrm{SD}=9.348)$ for School Social Movements co-curricular activities. This indicated that, although all the three categories of co-curricular activities influenced students' commitment to democratic values, they had different levels of influence. To determine whether the differences between the means of students' commitment to democratic values as observed in Table 3 were significantly different between each other, they were subjected to oneway ANOVA. The results for the one-way ANOVA test were presented as shown on Table 4.

\begin{tabular}{|c|c|c|c|c|c|}
\hline Source & Sum of Squares & df & Mean Square & F & p-value \\
\hline Intercept & 1974500.097 & 1 & 1974500.097 & 27994.253 & $<0.001$ \\
\hline Involved in Co-curricular Activities & 663.005 & 2 & 331.503 & 4.700 & 0.010 \\
\hline Error & 23980.995 & 340 & 70.532 & & \\
\hline Total & 2180819.000 & 343 & & & \\
\hline Corrected Total & 24644.000 & 342 & & & \\
\hline
\end{tabular}

Table 4: One-Way ANOVA for Students' Commitment to Democratic

Values in Accordance to Involvement in Co-Curricular Activities

Results in Table 6 showed that, there was a statistically significant difference between commitment to democratic values for students involved in talent enhancement, academic enhancement and social movement co-curricular activities $\mathrm{F}$ $(2,340)=4.70, p=0.01, p<0.05$. The study went further to find out which groups of co-curricular activities were different from each other using Tukey's' HSD Multiple Comparisons Test, result are presented in Table 5.

\begin{tabular}{|c|c|c|c|c|c|c|}
\hline $\begin{array}{c}\text { Co-curricular Activities } \\
\text { (I) }\end{array}$ & $\begin{array}{c}\text { Co-curricular Activities } \\
\text { (J) }\end{array}$ & $\begin{array}{c}\text { Mean } \\
\text { Difference } \\
\text { (I-J) }\end{array}$ & \multirow{2}{*}{$\begin{array}{c}\text { Std. } \\
\text { Error }\end{array}$} & & Sig. & \multicolumn{2}{|c|}{$\begin{array}{c}\mathbf{9 5} \text { Confidence } \\
\text { Interval }\end{array}$} \\
\cline { 3 - 7 } & & & & & $\begin{array}{c}\text { Lower } \\
\text { Bound }\end{array}$ & $\begin{array}{c}\text { Upper } \\
\text { Bound }\end{array}$ \\
\hline \multirow{2}{*}{ Talent Enhancement } & Academic Enhancement & $2.57^{*}$ & 1.041 & .037 & .12 & 5.03 \\
\cline { 2 - 7 } & School Social Movement & -.92 & 1.179 & .714 & -3.70 & 1.85 \\
\hline \multirow{2}{*}{ Academic Enhancement } & Talent Enhancement & $-2.57^{*}$ & 1.041 & .037 & -5.03 & -.12 \\
\cline { 2 - 7 } & School Social Movement & $-3.50^{*}$ & 1.255 & .016 & -6.45 & -.54 \\
\hline \multirow{2}{*}{ School Social Movement } & Talent Enhancement & .92 & 1.179 & .714 & -1.85 & 3.70 \\
\cline { 2 - 7 } & Academic Enhancement & $3.50^{*}$ & 1.255 & .016 & .54 & 6.45 \\
\hline
\end{tabular}

Table 5: Tukey's' HSD Multiple Comparisons Test for Students' Commitment to

Democratic Values in Percentages in Respect to Co-Curricular Activities

$*$ The Mean Difference Is Significant at $P<0.05$ Level 
A comparison of talent enhancement with academic enhancement co-curricular activities (see Table 5) revealed that there was statistically significant difference between them (Sig. $=0.037$, i.e. $p<0.05$ ). A comparison of Talent enhancement and school social movement further revealed there was no statistically significant difference between them (Sig. $=0.714$, i.e. $p>0.05$ ). In addition a comparison between academic enhancement and talent enhancement also revealed there was statistically significant difference between them ( Sig. $=0.037$, i.e. $p<0.05$ ) while a comparison between academic enhancement co-curricular activities and school social movement showed there was statistically significant difference between them (Sig. $=0.016$, i.e. $\mathrm{p}<0.05$ ).

A further comparison between school social movements and academic enhancement co-curricular activities revealed there was no statistically significant difference between them (Sig. $=0.714$, i.e. $p>0.05$ ) while statistically significant difference was found between school social movement and academic enhancement co-curricular activities (Sig. $=0.016$, i.e. $\mathrm{p}<0.05$ ). Hence the null hypothesis ( there is no statistically significant difference in commitment to democratic value) is supported between talent enhancement and school social movement where the means did not differ significantly. Table 6 shows where the similarities and differences between the groups lie.

\begin{tabular}{|c|c|c|c|}
\hline & & \multicolumn{2}{|c|}{ Subsets for $\mathbf{p}<\mathbf{0 . 0 5}$} \\
\hline Co-curricular Activities & $\mathrm{N}$ & 1 & 2 \\
\hline Academic Enhancement & 111 & 77.34 & \\
\hline Talent Enhancement & 157 & 79.92 & 79.92 \\
\hline School Social Movement & 75 & & 80.84 \\
\hline Sig. & & .070 & .707 \\
\hline
\end{tabular}

Table 6: Tukey's Homogeneous Subsets for Means of Students'

Commitment to Democratic Values in-Respect to Co-Curricular Activities

The Tukey's test found that the means for academic Enhancement and Talent enhancement (77.34 and 79.92 respectively) were not statistically different from each other. It also showed that, the means for Talent enhancement (79.92) and school social movement (80.84) were not statistically different from each other. The homogeneous sub-sets calculated by Tukey's test reveal two set in respect of the variable "Standardized mathematics score": (Academic Enhancement and Talent enhancement) and (Talent enhancement and school social movement). Multiple Regression was further used to weigh the influence of talent enhancement, academic enhancement and school social movements on students' commitment to democratic values. Results are shown in Table 7.

\begin{tabular}{|c|c|c|c|c|c|}
\hline $\begin{array}{c}\text { Categories Of Co-Curricular } \\
\text { Activities (CA) }\end{array}$ & \multicolumn{2}{|c|}{$\begin{array}{c}\text { Unstandardized } \\
\text { Coefficient }\end{array}$} & $\begin{array}{c}\text { Standardized } \\
\text { Coefficient }\end{array}$ & T-Ratio & P - Values \\
\cline { 2 - 5 } & B & Std. Error & Beta & & \\
\hline (Constant) & 76.187 & 1.375 & & 55.408 & 0.001 \\
\hline Talent Enhancement & .054 & .022 & .221 & 2.468 & 0.014 \\
\hline Academic Enhancement & .020 & .022 & .079 & .913 & 0.362 \\
\hline School Social Movement & .082 & .024 & .268 & 3.363 & 0.001 \\
\hline $\mathrm{R}^{2}=.047$ & & & & & \\
\hline F-ratio =5.563 & $\mathrm{P}<0.001$ & & & & \\
\hline $\mathrm{n}=343$ & & & & & \\
\hline
\end{tabular}

Table 7: Multiple Regressions for Effect of Involvement in Co-Curricular Activities on Students' Commitment to Democratic Values

Results in Table 7 revealed that the adjusted $\mathrm{R}^{2}(0.047)$, ANOVA $(\mathrm{p}<0.001)$ and the standardized $\beta$ coefficient of each component variable $(\beta=0.268, p=0.001), \beta=0.221, P=0.014, \beta=0.079, p=0.362)$. This implies that relative to each other, school social movement exerted the greatest and positive influence on students' commitment to democratic values followed by talent enhancement and academic enhancement. These influences were statistically significant $(p<0.05)$. Hence the null hypothesis is rejected and the alternative hypothesis that there is statistically significant difference in commitment to democratic values among students involved in talent enhancement, academic enhancement and school social movements is supported.

These results confirmed that, different categories of co-curricular activities yielded different magnitude of influence on students' commitment to democratic values. The variations could be attributed to variation in ideals, formation and operation of the groups. For instant, Student Social Movements such as scout associations are perpetual school groups with strong inclination and adherence to their parent movement, Kenya Scout Association, (Ombaka, 1994). Irrespective of type or nature of schools, members of scout associations are expected to adhere to scout rules, which are universal to all its chapters. This creates a strong platform for inculcating commitment to democratic values (Cunningham, 2000).

Talent Enhancement co-curricular activities (sports teams, drama clubs music clubs) in public secondary schools are majorly adhoc students groups, created every season of inter-school competitions organized by Departments of Education (Pate, 2015). Therefore, they have no permanent members and their principle role is to represent school in prevail competitions at a given time. In most public secondary schools these co-curricular activities cease to exist 
immediately after competitions period. Although these activities reflected fair influence on commitment to democratic values, its temporary nature in membership and operations weakens its ability of inculcating democratic values.

Academic Enhancement co-curricular activities, which included science clubs, geography clubs and debate clubs had the least influence on commitment to democratic values. These findings could be attributed to their strong attachment to academic subject content and lack of flexibility to accommodate inculcation of democratic values. In most instances Academic Enhancement co-curricular activities operate as extension of classroom environment under peer guidance. Hence the findings of this study, various categories of co-curricular activities yield different magnitudes of influence on students' commitment to democratic values are plausible.

\section{Conclusion}

Involvement in co-curricular activities has positive influence on students' commitment to democratic values. Further to positive influence, in comparison, school social movements have higher influence on student's commitment to democratic values, followed by talent enhancement and lastly academic enhancement co-curricular activities. Hence in prioritization of inculcation of commitment to democratic values among students through co-curricular activities, school social movements should be given higher preference followed by talent enhancement. The academic enhancement activities should be given least preference.

\section{Recommendation}

Co-curricular activities need to be adopted as one of the schools core framework for integration of national democratic values among students owing to their wide scope of involvement and high influence on students' commitment to democratic values. There should be deliberate efforts to increase enrolment of students' in school social movements considering their high influence on students' commitment to democratic values.

\section{References}

i. Ahmed Sakr Ashour (2004) Transparency and Accountability in the Public Sector in the Arab

ii. Region. UNDESA RAB/ 01/ 006.

iii. Cunningham, J. (2000). Democratic Practices in School, Citizenship and Democracy in schools. Washigton D.C.: Trenthan Books Graham.

iv. Chemutai, F. (2008). The Students Attitude Towards CRE and its Influence on Performance in School in Eldoret Municipality, Uasin Gishu District, Kenya (Unpublished M. Phil Thesis). Moi University, Eldoret.

v. Cohen, C., \& Sterba, J. P. (2003). Affirmative action and racial preference: A debate. Oxford [England: Oxford University Press

vi. Dahl, R. (1998). Democracy and its Critics. New Havean: Yale University Press.

vii. Daily Nation (2008). Schools unrest sign of changed society. 27 July 2008 p.6 col.2-4: Posted by Nairobi chronicle.

viii. Daily Nation (2018). School officials fail to implement solutions to unrest

ix. $\quad$ Saturday July 72018

x. Gaffoor, A. K. ( 2015). Validation of Scale of Commitment to Democratic Values. Guru Journal of Behavioral and Social Sciences Volume 3, Jan - March 2017, 361 - 373.

xi. Gafoor, K. A. (2010). CBSE and state school students' values of nationalism internationalism

xii. and social justice. Journal of Community Guidance and Research 27 (2), 202-210.

xiii. Mehmood, T. (2012). Impact of Co-Curricular Activitieson Personality Development of Secondary Students. International Journal of Humanities and Social Sciences Vol. 2 No.18.

xiv. Okumbe, J. (1998). Education Management: Theory and Practice. Nairobi: University of Nairobi Press.

xv. Oluoch, Gilbert Paul, "Curriculum development : toward effecting improvement in Kenya schools." (1977). Doctoral Dissertations 1896 - February 2014.2237.

xvi. https:// scholarworks.umass.edu/ dissertations_1/2237

xvii. Pate, R. (2015). The way of the athlete: The role of sports in building character for academic, business, and personal success.

xviii. Smist, J. A. (2011). Co-curricular programs. In S. R. Komives, J. P. Dugan, J. E. Owen, C. Slack, \& W. Wagner (Eds.), The handbook for student leadership development (2nd ed.). San Francisco: Jossey-Bass

xix. Tyler, M. C. (1949). A history of American literature, 1607-1765. Ithaca: Cornell University

xx. Weber, S. (2001). Globalization and the European political economy. New York: Columbia University Press. 